\title{
CURRENT STATUS OF THE METAL POLLUTION OF THE ENVIRONMENT OF GREECE - A REVIEW
}

\author{
E.G. FARMAKI ${ }^{1,2}$ \\ N.S. THOMAIDIS ${ }^{1, *}$
}

\author{
${ }^{1}$ Laboratory of Analytical Chemistry, Department of Chemistry \\ National and Kapodistrian University of Athens \\ Panepistimioupolis, 15771 Zografou, Athens, Greece \\ ${ }^{2}$ Athens Water Supply and Sewerage Company (EYDAP S.A.) \\ Water Quality Control and Protection Division \\ Polydendri Attikis, Greece
}

Received: 02/04/08

Accepted: 30/06/08 *to whom all correspondence should be addressed: e-mail: ntho@chem.uoa.gr

\begin{abstract}
Pollution from metals and metalloids of the environment of Greece seemed to attract many researchers and elemental pollutants in air, soil and water have been determined and studied systematically during the last decade. The most recent of these studies, concerning the last five years (2003 to 2008), were reviewed and the major problems of the occurrence of heavy metals in the country's environment were pointed out.

Regarding the atmospheric environment, the chemical characterization of particulate matter of the big Greek cities attracted the interest of many authors. Heavy metals and As represented an important fraction of the particulate matter of the atmosphere of Greek cities, with increased content in inhalable fraction.

In addition, many works studied the metal content of soil and plants of the Athenian forests, among with agricultural soils from the countryside. Copper, Fe and Cd were identified as the most accumulated metals that may pose a long-term threat to soil and aquatic environment.

Most of the reviewed articles concerned the aquatic environment. Rivers and coastal environment of northern Greece presented increased levels of metals and arsenic, reflecting the transboundary and local agricultural and industrial activities. Marine environment nearby the big cities was found reasonably polluted.

Therefore the presented results reflected the human activities: urban areas were reasonably found more polluted (however without severe exceedence of the regulated values), compared with the less populated regions. On the contrary, drinking water of the urban populated areas, due to proper treatment, conformed to the regulated values.
\end{abstract}

KEYWORDS: Metals, Metalloids, Air, Soil, Plants, Aquatic Environment, Greece.

\section{INTRODUCTION}

The quality of the environment is a matter of serious concern, especially today that the consequences of human intervention are already evident. Although environment is extremely valuable for people and other organisms living in it, it is also endangered due to human activities that are continuously ruining it (Davis et al., 2006). Air and water accept any kind of pollutants produced mainly from industries, but also naturally, domestic or traffic originated. Gaseous pollutants and particulate matter are emitted to the atmosphere, while sea water, rivers and lakes are often used to carry off the municipal and industrial wastewater. Metals and metalloids due to their extensive use represent an important fraction of the pollutants released in air, soil and water. They really seem to be ubiquitous today (Merian et al., 1991). Cement and metal industries and mines, fossil fuel combustion, road dust and traffic, contribute frequently uncontrollably, to the environmental pollution. They occur naturally as 
ions, compounds and complexes (speciation) in the environment (air, soil, plants and water) in a variety of forms. Additionally, metals that used to exist in traces in the environment due to natural sources, have become hazardous nowadays, due to the extreme human contribution. Many of them are usually extracted, purified and processed for industrial use and then released to the environment again. Natural or other urban sources contribute accumulatively. Processes like soil erosion, rock weathering and volcanoes' eruptions seem to accumulate the final effects. Comparative data for land, atmosphere and aquatic environment indicate metals and metalloids as the most potentially hazardous water and soil pollutants. As a result of global and regional redistribution and conversion, living organisms can be exposed to them locally through inhalation, skin contact and consumption. Moreover, metals and metalloids seem to be present in every foodstuff, as a result of bioaccumulation from marine organisms and plants to animals and human. Therefore bioaccumulation, the basic characteristic of the metallic elements, aggravates the problem.

Consequently, metals and metalloids represent important parameters for air, soil and water quality and safety. Regulatory bodies worldwide set limits in order to control their amount releasing in air or entering soil, water reservoirs or sea through industrial and not only discharges.

In Greece, metal analysis in air, soil and water have seen a continuously increased interest over the last decade by research groups. Many studies concerning metal pollution in the aforementioned environmental compartments have been recorded during 2003 to 2008 . Thus, this review focuses on recent key-articles, concerning environmental pollution from metals in Greece, aiming at recording the metal pollution problem in the country. Three critical categories seem to focus the interest of the authors' majority: air, soil and plants and aquatic environment (drinking, underground and surface fresh or sea water). Therefore, this structure will be kept for the sections presented below.

\section{ATMOSPHERIC ENVIRONMENT}

Concerning air pollution, the airborne particles have been recognized as a significant air quality parameter due to their impact on the environment and human health, as shown from the increased number of publications. The interest for the characterization of airborne particles in polluted areas was initially due to their contribution on visibility reduction (Davis et al., 2006). This interest has been recently increased due to the results of epidemiological studies showing a strong correlation between elevated concentrations of fine particulate matter (PM) and mortality (Dockery and Pope, 1994). Thus, nowadays, there is a serious concern about health impact, especially in densely populated areas or in work places that gases or particles are emitted.

The elemental characterization of airborne PM10 and PM2.5 particles consists one of the major research issues in Greece during the last years. The studies concern mainly the two big urban regions of the country, Athens and Thessaloniki. During the 5-years period (20032008), six papers dealt with the determination of metallic elements of the particulate matter in the atmosphere of these two densely populated cities.

The concentrations of $\mathrm{Pb}, \mathrm{Cd}$, As and $\mathrm{Ni}$ in PM2.5 particles were measured in Athens atmosphere, in the first study published in 2003 (Thomaidis et al., 2003). The sampling was performed during March 1995 to March 1996 and two sites were selected: an urban (Patission) and an industrial / semi-urban area (Rentis). The annual geometric mean values of the metals measured in PM2.5 particles samples did not exceed EU proposed limits for PM10 particles (EU-WHO, 2002). As and Ni presented higher levels at Rentis station. Pb showed higher values during winter. Principal Component Analysis (PCA) was applied on the data for source apportionment of toxic elements in PM2.5 particles. Thus, Pb, As and Ni seemed to have common sources, which could be vehicles emissions/oil combustion and re-suspended road dust. Cd and a portion of As originated from industrial activities.

The second study concerned the size distributions of airborne particulate matter and associated heavy metals at a traffic-orientated urban site in Thessaloniki and published in 2005 (Samara and Voutsa, 2005). Sampling campaigns were conducted during the period of March 1999 to May 2000 and the particulate matter was categorized in five inhalable 
fractions: $<0.8 \mu \mathrm{m}, 0.8-1.3 \mu \mathrm{m}, 1.3-2.7 \mu \mathrm{m}, 2.7-6.7 \mu \mathrm{m}$ and $>6.7 \mu \mathrm{m}$. Most of the airborne PM mass $(52 \%)$ contained in the submicron size range $(<0.8 \mu \mathrm{m})$ and an additional minor mode $(20 \%)$ in the coarse size fraction $(>6.7 \mu \mathrm{m})$. However, the predominance of PM and toxic heavy metals, such as $\mathrm{Pb}, \mathrm{Cd}, \mathrm{Ni}$ and $\mathrm{V}$ in the submicron particle fraction $(<0.8 \mu \mathrm{m})$, being deeply inhaled in the lungs, might increase the risk for disease, particularly in individuals spending long time in the roadside environment. Statistical analysis (Factor Analysis) of distribution data indicated a combination of processes including natural aerosol sources and anthropogenic, such as traffic, industrial emissions and resuspension of road dust.

Published also in 2005, the next work, presented results from a particulate matter measurement campaign, conducted across the greater Athens area, at four locations, during June 2001 to May 2002 (Manalis et al., 2005). The collected 24-h samples (PM10 fraction) were analyzed for $\mathrm{Pb}, \mathrm{As}, \mathrm{Cd}, \mathrm{Ni}, \mathrm{Cr}, \mathrm{Mn}, \mathrm{V}, \mathrm{Cu}$ and $\mathrm{Hg}$. From these elements, only As levels exceeded the assessment threshold at two sites. Moreover, site-specific correlation analysis was conducted for the identification of metals with similar origin. Thus, vehicle-related sources seemed to be the most important source, while $\mathrm{Cu}$ was most closely linked with the road transport factor.

The chemical characterization of the PM10 particles was the research object of the fourth study published in 2007 (Vassilakos et al., 2007). The sampling campaign was conducted during summer of 2002 and winter of 2003, at two different sites in the Messogia basin, northeast of Athens. The aim of the study was to explore the variations of heavy metals in PM10 and examine their relationship with gaseous pollutants and meteorological parameters. The $\mathrm{Hg}, \mathrm{Cd}, \mathrm{Pb}, \mathrm{Ni}$ and $\mathrm{As}$ content were determined. PM10 contents in $\mathrm{Hg}, \mathrm{Cd}$ and $\mathrm{Ni}$ showed regular daily variations, with higher mass percentages during summer, while PM10 $\mathrm{Pb}$ presented higher mass percentages during winter. Moreover, especially for $\mathrm{Pb}$, examination of the relationship between heavy metals and meteorological parameters indicated a high correlation with temperature and relative humidity. Generally, correlations with meteorological parameters and gaseous pollutants were higher during winter. Maximum heavy metal concentrations at both sites were observed during days with NE or NNE prevailing winds during summer, while the winter period was characterized with maximum values during days with $\mathrm{W}$ or WNW prevailing winds.

Published also in 2007, the next study focused on measuring heavy metals contents in aerosol samples collected from June to July 2001 in a central avenue (Patission) of Athens, characterized by heavy traffic (Karanasiou et al., 2007). The results showed that metals such as $\mathrm{Cd}, \mathrm{V}$ and Ni were characterized by mass median diameter (MMD) $<1 \mu \mathrm{m}$, while the MMD for $\mathrm{Pb}$ and $\mathrm{Mn}$ were similar to $1 \mu \mathrm{m}$ and metals such as $\mathrm{Al}, \mathrm{Fe}, \mathrm{Cu}$ and $\mathrm{Cr}$ were found to have $M M D=2-6 \mu \mathrm{m}$. According to authors' opinion, the first two groups of metals were ascribed to anthropogenic emission sources (like vehicle emissions), while the last one was ascribed to soil dust or mechanical abrasion processes.

In 2008, a study concerned the determination of $\mathrm{Zn}, \mathrm{Pb}, \mathrm{Cd}$ and $\mathrm{Cu}$ in the coarse (PM10-2.5) and fine (PM2.5) fraction of aerosol samples was published (Ochsenkuhn et al., 2008). Aerosol samples were collected during June 2005 to May 2006 from the industrial area of Aspropyrgos (Attica, Greece) and the determination of $\mathrm{Zn}, \mathrm{Pb}, \mathrm{Cd}$ and $\mathrm{Cu}$ was carried out using anodic stripping voltammetry. The authors indicated a nearby located steel industry as the main source for $\mathrm{Zn}, \mathrm{Cd}$ and $\mathrm{Pb}$, while the presence of $\mathrm{Cu}$ was attributed to the abrasion of the cables of the railroad line, electrified a short time ago. Cd and $\mathrm{Zn}$ were also attributed to the metal treatment at the shipyards of the region.

In conclusion, heavy metals and As represent an important fraction of the PM of the atmosphere of Greek cities, with increased content in inhalable fraction. Vehicles emissions/oil combustion, industrial emissions and re-suspended road dust seem to be the most important pollution sources.

\section{SOIL AND PLANTS}

Soil has high retention capacity due to its cation exchange and complexing with organic substances abilities (Riga-Karandinos et al., 2006). 
In agricultural regions, soil degradation is usually occurred due to the agrochemicals addition (fertilizers and pesticides) to crops and ground. Significant amounts of many heavy metals are contained in these additives and thus human consumers and plants are often exposed to the metal toxic effects, due to the usual long-term application. On the contrary, metal pollution in urban soils may originate from a variant of human activities, like dense traffic, industries, construction works, fuel combustion and waste disposal.

Six articles concerning the current metal pollution in soil and plants are reviewed in this work. A study, published in 2005, examined the distribution and cycling of $\mathrm{Pb}$ in an urban forest of Aleppo pine in Athens (Michopoulos et al., 2005). Sampling of rain water (bulk and throughfall), forest floor and litterfall, pine needles, wood and bark biomass and mineral soil was performed during the period 2001 - 2002. The soluble fraction of $\mathrm{Pb}$ in bulk and throughfall deposition was low, reflecting the change in petrol type (lead free) in recent years. The results obtained in that study were similar to those found in remote forests. However, the undissolved dry deposition of urban environments could not be underestimated: $\mathrm{Pb}$ concentrations in forest floor and mineral soil remained high due to metal accumulation from previous years. In pine needles, litterfall and wood, $\mathrm{Pb}$ concentrations were low, while bark stored high amounts of the metal.

Published in 2006, the following work concerned the measurements of $\mathrm{Pt}, \mathrm{Pd}, \mathrm{Pb}, \mathrm{Cu}, \mathrm{Zn}, \mathrm{Fe}$, and $\mathrm{Ca}$ concentrations in roadside top-soil samples in the greater Athens area (RigaKarandinos et al., 2006). During May 2003, four types of sites have been sampled: urban, suburban, rural and highway. The results indicated increased concentrations of the metals $\mathrm{Pb}, \mathrm{Cu}, \mathrm{Zn}, \mathrm{Pt}$ and $\mathrm{Pd}$ in top-soils of a highway and urban street in Athens. However, the levels of these pollutants in suburban and rural roads decreased significantly. The authors supported the existence of a common source (catalytic converters) for Pt and Pd due to the relatively constant ratios between them. Finally, statistical methods like Cluster Analysis (CA) and Principal Component Analysis (PCA) were used for revealing the variables' correlations.

The purpose of the third study was to estimate the heavy metal pollution due to agrochemical contamination in agricultural soils of the hydrological basin of Keritis, in Chania, in the island of Crete (Papafilippaki et al., 2007). The total heavy metal concentrations in Keritis soils were similar to the total concentrations in other agricultural areas and the studied soils could not be described as heavily polluted. Moreover, the bioavailable concentrations of $\mathrm{Cu}, \mathrm{Zn}, \mathrm{Pb}$ and $\mathrm{Cr}$ were low. The relative availability and consequently the comparative mobility of the studied metals followed the order: $\mathrm{Cu}>\mathrm{Pb}>\mathrm{Zn}>\mathrm{Cr}$, also observed by other researchers. According to the authors' opinion, organic matter has played a significant role in the availability and mobility of the heavy metals in soils. Humified organic matter seemed to be involved in the formation of soluble complexes with $\mathrm{Cu}$ and $\mathrm{Zn}$, while $\mathrm{Cr}(\mathrm{VI})$ was reduced to $\mathrm{Cr}(\mathrm{III})$ which is relatively immobile in the presence of organic matter.

The fourth study was conducted during the years 2003 and 2004. The trace element analysis of Aleppo pine as a function of tree age was achieved by the tree-ring sampling method, in a polluted region of Athens (Pantera et al., 2007). Industrial and traffic originated pollution contributed to the total burden of the area. Sections of 10 years each were identified and separated from tree samples and for the time period from 1870 to 2003, generating samples of 14 decades. The comparison of the precipitation curves of the hydrological years with the annual tree width of the period 1870 to 2003 revealed that the tendency line of tree-ring width follows the precipitation tendency, also documented by previous authors. Moreover, with the exception of $\mathrm{Pb}$ that decreased after the 1980 to 1989 decade, the other elements tended to increase during the study period. Cu indicated three peaks during the decades 1920 to 1929 , 1960 to 1969 and 1990 to 1999, which was attributed to atmospheric pollution. Fe concentrations showed an enormous increase during the last decades. No changes were noted from 1870 to 1930 , following an abrupt increase. This change was attributed to the opening of a major steel plant, located to the area. $\mathrm{Zn}$ concentrations have remained constant. Mn concentration showed various fluctuations, ending to a similar to the initial level. Finally, according to authors' opinion, it appeared that tree ring elements responded to environmental inputs. Soil, litter, air deposits and water seemed to be important nutrient sources contributing to changes in elemental concentration in the annual rings. 
The nutrient cycling and foliar status for the elements $\mathrm{Mg}, \mathrm{Fe}, \mathrm{Mn}, \mathrm{Zn}$ and $\mathrm{Cu}$ (among others) were investigated in an urban (2.8 km from the city centre) forest of Aleppo pine in 2004 in Athens, in order to estimate the productivity status and health of the ecosystem, in a study published in 2007 (Michopoulos et al., 2007). The sampling campaigns included bulk and through fall wet deposition, forest floor and mineral soil, needles, litterfall, understory vegetation, wood and bulk tissues. From that study, the following conclusion should be emphasized:

(a) The trunk wood contained higher amounts of $\mathrm{Mg}, \mathrm{K}, \mathrm{N}, \mathrm{Mn}$ and $\mathrm{Zn}$, whereas the trunk bark stored higher amounts of $\mathrm{Fe}$ and $\mathrm{Cu}$.

(b) The amounts of $\mathrm{Cu}$ and $\mathrm{Zn}$ in the forest floor were found to be well below the upper toxicity limits set for a $15 \mathrm{~cm}$ soil depth (Rowell 1994). The amount of Fe stored in the Aleppo pine forest floor was three times as high, compared with analogous studies (Whittaker et al., 1979), in contrast with Mn, that seemed to be lower.

(c) The statistical analysis showed that the needles of the Aleppo pine trees in Athens had significantly higher concentrations of $\mathrm{Cu}$ and lower concentrations of $\mathrm{Mg}$ and $\mathrm{Zn}$, compared to results found in pine needles in Spain.

A recent study (published in 2008), dealt with heavy metals determination in forest, agricultural and industrial surface soil samples in relation to pre-anthropogenic soils of Almyros region, in central Greece (Golia et al., 2008a). The samples were collected during the period 2004 to 2005 and analysed for the bioavailable and total $\mathrm{Cd}, \mathrm{Cr}, \mathrm{Cu}, \mathrm{Pb}, \mathrm{Zn}$ and $\mathrm{Ni}$ content. The results showed that both the agricultural and the industrial soils were contaminated. Bioavailable $\mathrm{Cd}$ had the highest values in agricultural soils. This was attributed to the high amounts of fertilizers used in the area. High amounts of $\mathrm{Pb}$ were related to the traffic conditions due to the high way connecting Athens - Thessaloniki that crosses the studied area. The concentrations of metals in the region seemed to be lower than in other investigations, in forest, agricultural and industrial soil samples, in Greece or other countries, as well (Mitsios et al., 2005; Golia et al., 2007, 2008b; Wong et al., 2002; Micó et al., 2007; Yoon et al., 2007; Martin et al., 2006; Peris et al., 2007).

In conclusion, the review on soil and plant analyses shows that $\mathrm{Fe}$ and $\mathrm{Cu}$ are the most accumulated elements in plants, labile Cu complexes may pose a threat on the microcosm of soil and water, whereas labile $\mathrm{Cd}$ remain a significant problem of the agricultural soil pollution due to extensive use of fertilizers.

\section{AQUATIC ENVIRONMENT}

Industrial and domestic activities contribute to the release of significant amounts of metals among other toxic substances into the marine environment and directly affect surface water and quality of sediments. Many studies have been published during the last five years, focusing on water pollution. Toxic metals like $\mathrm{Cd}, \mathrm{Pb}, \mathrm{Cu}, \mathrm{Zn}, \mathrm{Hg}$ that are naturally in traces seem to attract the interest of researchers. In addition, the lower are the natural levels of the metal in the environment, the critical are the even low external additions (Merian et al., 1991). In Greece, most authors dealt with the metal load on aquatic environment. Some of the keyarticles of 2003-2008 period, dealt with metal water pollution, will be mentioned here and they will be presented in chronological order divided into three main categories: drinking and ground water, river and lake water and marine environment.

\subsection{Drinking and ground water}

The geological and hydrogeological conditions of Mesogea basin, was the object of a research published in 2006 (Stamatis et al., 2006). The sampling campaign concerned 51 wells and 34 boreholes in eastern Attica and determinations of $\mathrm{Fe}, \mathrm{Mg}, \mathrm{Cu}$ and $\mathrm{Zn}$ were performed. The results confirmed pollution due to extensive anthropogenic activities (construction works, intensive agricultural activity, operation of the new international airport of Athens, small industrial units and dense highway network). In most of the samples, $\mathrm{Cu}$ concentrations exceed the regulated level (EC, 1998) (perhaps due to cultivations of vineyards, where cooper sulphate is used), while, on the contrary, $\mathrm{Fe}$, with the exception of one case, did not exceed the highest allowable level. Mg presented slight higher 
concentrations than the indicative values and finally $\mathrm{Zn}$ had low levels. The quantity of groundwater in the study area seemed to be adequate to satisfy the local needs.

Drinking water from various regions all over Greece was studied in a recent work published in 2008 (Karavoltsos et al., 2008). Nine geographical areas of Greece have been studied and many pollutants were measured. Metals like $\mathrm{Cd}, \mathrm{Cu}, \mathrm{Pb}, \mathrm{Cr}, \mathrm{Ni}$ were among them. The majority of problems were identified in the Cyclades islands particularly those characterized by scarcity of water resources. Thus, inhabitants are forced to store water in domestic tanks, not always appropriate. Generally, the main problems related to drinking water quality were associated with the conditions of the water supply networks, the pollution of 'parent' water and the contamination of groundwater with pollutants of both anthropogenic and natural origin, or the intrusion of seawater in aquifers. According to authors' results, $\mathrm{Pb}$ levels exceeded the regulated parametric value of $10 \mathrm{\mu g} \mathrm{L}^{-1}$ (EC, 1998) in the most regions, excluding Attica, Dodecanese islands and Peloponnese.

\subsection{Surface water}

Extensive data of previous works were used in a study published in 2003 (Karageorgis et al., 2003). Results of heavy metals (dissolved and particulate) among other pollutants were reviewed for Axios river water and sediments. $\mathrm{Zn}, \mathrm{Pb}, \mathrm{Cr}$ and As levels appeared to be elevated. A significant part of these metals originated naturally, while, smelting industries of FYROM also seemed to contribute in a major degree to the heavy metal pollution of the total area. Marine sediments of the Thermaikos Gulf clearly reflected heavy metal sources, namely Axios and Aliakmon rivers, as well as the urban and industrial zone of Thessaloniki. $\mathrm{Pb}$ values of Axios River exceeded the drinking water criteria, whereas, sediments quality criteria were exceeded for As and $\mathrm{Cr}$, in both river and marine sediments. Increased accumulations of heavy metals, such as $\mathrm{Cr}$ and As, have also been observed in the Thermaikos Gulf and they were directly attributed to the Axios (and Aliakmon) river loads.

Statistical multivariable techniques were used for the water quality assessment in the major river systems (Aliakmon, Axios, Gallikos, Loudias and Strymon) as well as streams, tributaries and ditches of northern Greece (Simeonov et al., 2003). The dataset consisted of analytical results from a 3-year survey and included toxic elements like $\mathrm{Ag}, \mathrm{As}, \mathrm{B}, \mathrm{Ba}, \mathrm{Cd}, \mathrm{Cr}, \mathrm{Cu}, \mathrm{Hg}$, $\mathrm{Fe}, \mathrm{Mn}, \mathrm{Ni}, \mathrm{Pb}$, Se and $\mathrm{Zn}$. Exceedence (according to EC 98/83 directive for potable water) (EC, 1998), were observed for $\mathrm{Mn}, \mathrm{Fe}, \mathrm{Pb}$ in some cases. PCA applied on the data, indicated six latent components, three of which reflected metal contributions: $B$ and $B a$ in the fourth $P C$ (representing rock weathering processes), $\mathrm{Cu}, \mathrm{Cr}, \mathrm{Ni}, \mathrm{Mn}$ and $\mathrm{Fe}$ in the fifth $\mathrm{PC}$ (tracing soil leaching processes) and $\mathrm{Pb}, \mathrm{Zn}$ and $\mathrm{Cd}$ in the last $\mathrm{PC}$ (anthropogenic-toxic impact).

Fifteen (15) sampling sites were selected from the Athens reservoirs (Iliki, Mornos and Marathon), under the quality control monitoring program of EYDAP company, during six sampling campaigns from November 2006 to April 2007 for the determination of metals and metalloids (Farmaki, 2007). The results concerned the dissolved and total fraction of 13 elements: $\mathrm{Fe}, \mathrm{B}, \mathrm{Al}, \mathrm{V}, \mathrm{Cr}, \mathrm{Mn}, \mathrm{Ni}, \mathrm{Cu}, \mathrm{Zn}, \mathrm{As}, \mathrm{Cd}, \mathrm{Ba}$ and $\mathrm{Pb}$. That work focused on the dissolved / bioavailable percentages: all the elements' values fluctuated in low levels. Generally, higher levels of $\mathrm{Mn}, \mathrm{Ni}, \mathrm{As}, \mathrm{B}, \mathrm{Fe}, \mathrm{Cu}$ were measured in Marathon due to anthropogenic activities (mainly agricultural), while lliki was affected strongly by industrial, domestic and agricultural pollution sources. However, no exceedence from the regulated values was recorded. Mornos seemed to be free from every type of metal burden.

Water from Gallikos River, its tributaries and adjacent drills (Northern Greece) was sampled during 2004 to 2005 in periods that represented the highest and lowest ground and surface water levels (Mattas et al., 2007). Surface water quality deterioration was mainly attributed to anthropogenic pollution. Groundwater samples were also affected by surface water pollution, as this river was its main water supplier. Finally, protection of both surface and groundwater was proposed by the authors and industrial and domestic effluent treatment plants judged to be necessary for the whole area.

Water quality and quantity of Kosynthos river (north-eastern Greece) was assessed in the next study, also published in 2007 (Pisinaras et al., 2007). Sampling campaigns were conducted between October 2003 and October 2005. Heavy metals like $\mathrm{Cu}, \mathrm{Fe}, \mathrm{Zn}, \mathrm{Mn}, \mathrm{Pb}$, 
$\mathrm{Cr}, \mathrm{Ni}$ and $\mathrm{Cd}$ were determined among others pollutants. Four monitoring sites have been selected and one of them (the most downstream) proved to be the most polluted because of urban and agricultural runoff. The levels of $\mathrm{Ni}, \mathrm{Cd}$ and $\mathrm{Pb}$ showed little variations between different monitoring sites, suggesting influence from the geological deposits rather than from point sources. The highest concentrations for $\mathrm{Cu}, \mathrm{Fe}, \mathrm{Zn}, \mathrm{Mn}, \mathrm{Pb}, \mathrm{Cr}, \mathrm{Ni}$ and $\mathrm{Cd}$ were exceeded the WHO limits (WHO, 1984) for drinking water. The source was considered to be natural (geological formations) by the authors, documented by the existence of mining facilities located in the area.

Polyphytos artificial reservoir is located in Aliakmon river in Kozani (north-western Greece). It was created to cover water needs mainly for hydropower and irrigation. Additional uses comprise water supply for the adjacent area (including the big city of Thessaloniki), fishing and recreation. A recent published study presented the results of a monitoring program conducted in the area (Gikas et al, 2008). The mean concentrations of metals $\mathrm{Fe}, \mathrm{Mn}, \mathrm{Cu}, \mathrm{Cr}$, $\mathrm{Pb}$ and $\mathrm{Cd}$ in the lake water were found below the potable water standards set by WHO (WHO, 1984) and EC (EC, 1998). However, the metals $\mathrm{Fe}, \mathrm{Mn}, \mathrm{Pb}, \mathrm{Ni}$ and $\mathrm{Cd}$ were occasionally measured above these aforementioned quality standards. For these reasons, the authors recommend intensive monitoring of the lake and appropriate water treatment.

\subsection{Marine environment}

A study regarding Euvoikos Gulf in central Greece published in 2003 (Dassenakis et al., 2003). The specific area has a particular interest due to the significant tidal phenomena that are observed there. A strong tidal current that changes its direction every $6 \mathrm{~h}$ develops in the narrow straits that delimit the gulf. Extensive industrial activities affect the quality of the environment of the total area. Sediments samples have been collected during 1997 and the results indicated the impact of polluting activities in recent surface sediments. An increase of metal concentrations has been observed in comparison with previous periods. However, some environmentally positive signs, such as the reduction of mobile metals were also observed. Besides, the overall hydrological regime of the area favours its rapid restoration by allowing nature to act for the self-purification of the system.

The next study examined the concentrations of $\mathrm{Cd}, \mathrm{Cu}, \mathrm{Mn}, \mathrm{Ni}, \mathrm{Pb}$ and $\mathrm{Zn}$ in 2004 in Saronikos Gulf, which is mainly affected by anthropogenic inputs from the nearby metropolitan area of Athens (Scoullos et al., 2007). It is Interesting that the samples have been collected after the decennial operation of the Wastewater Treatment Plant of Athens and a few months before the inauguration of the secondary treatment. The results indicated a rather "steady state" concerning the level of trace metals in the marine environment of the Saronikos Gulf compared to the period before 2000. Furthermore, the contribution of other coastal and marine sources of metals in the area seemed to gradually increase and become comparable or even higher than that of the treated wastewater effluents. Further monitoring was strongly recommended by the authors targeting in the evaluation of the secondary treatment plant initiated after the current samplings.

The next study focused on the distribution of the various forms of $\mathrm{Cu}$ and $\mathrm{Cd}$ in the main layers of coastal algal mats in a closed bay at Anavissos, on the coast of Saronikos Gulf (Ladakis et al., 2007). Both metals are considered to be dangerous pollutants, human originated. Moreover, the existence of the cyanobacterial mat on the surface of the sediment, the geological background and the human activities seemed to influence the temporal, spatial and fractional distribution of $\mathrm{Cd}$ and $\mathrm{Cu}$. The highest values for $\mathrm{Cd}$ were recorded during spring and the lowest during autumn, whereas the highest values for $\mathrm{Cu}$ were recorded during summer and the lowest during spring. Cd was mostly adsorbed in the sediment's small inorganic particles and carbonates. Crystal lattice fraction of $\mathrm{Cd}$ did not exceed $20 \%$ indicating that its origin was mostly human. The increased mobility of this metal was considered a possible danger to the ecosystem. The main fraction of $\mathrm{Cu}$ was strongly connected in alumino-silicate lattice and the metal showed increased seasonal fluctuation, in the surface layer of the sediment. Finally, the authors concluded that the under study sediments were partially contaminated with $\mathrm{Cd}$ but not with $\mathrm{Cu}$.

The next study was conducted in the framework of MEDPOL phase III (2004 to 2006) and aimed to provide information for the long-term monitoring of pollution trends in selected 
marine environments along the Mediterranean coastline (Aloupi et al., 2007). Four sampling stations along the eastern coast of island Lesvos (Greece) were used, including a high risk site near the harbour of the city of Mytilini. Among other pollutants, metals have been measured in sediments samples and two fish species. In the first case, metal concentrations were found to be lower compared to other polluted areas in Greece, but similar to other areas in the eastern and central Aegean Sea or in closed sea-water bodies in Greece. Concerning biota, metal concentrations in the fish flesh were similar in both species, with the exception of $\mathrm{Hg}$ which gave higher values in benthic species compared to the pelagic ones. The authors confirmed similar results of older studies. Generally, metal concentrations measured in both fish species have shown great variability, but they were very low compared to already reported values from other coastal areas of Greece or of the Mediterranean basin. Finally, there was no evidence of substantial pollution of the marine environment with respect to the pollutants measured. The only exception was the harbour of Mytilini city, in which sediments seemed to carry increased loads of anthropogenic metals.

\section{CONCLUSIONS}

A five-years publishing activity, concerning the current metal pollution of the environment of Greece (air, soil and water), was reviewed.

The chemical characterization of atmospheric particulate matter seemed to be the interest of many authors dealt with the air pollution in Greece. The two big cities (Athens city, the capital of Greece and Thessaloniki in the centre of Macedonia), attract the attention of the Greek researchers. However, the metal pollution found to be lower than the regulated limits for metal content in PM10 particles in both cities.

On the contrary, soils in Athens seem to be polluted concerning metal burden, while the same situation was observed in the examined pine trees' bark in the urban forests. Pollution from copper, iron and cadmium seem to be the most serious problem, especially in areas with intensive agricultural or/and industrial activity. Rain water (bulk and through fall) in forest areas was found unpolluted. Soil and plants in smaller cities seemed to be affected less by human activities.

A similar pattern was recorded for aquatic environment: surface water, marine sediments, gulfs and harbours near the big cities were reasonably found polluted, in the contrary with less populated areas. Rivers and coastal waters in Macedonia, northern Greece, showed increased levels of metals and arsenic. On the contrary, drinking water of the more developed and populated areas fulfilled the relative regulations, due to proper water treatment and intensive quality control programs.

\section{REFERENCES}

1. Aloupi M., Angelidis M.O., Gabriel A., Karantanelli M., Koulousaris M., Nikolaou A., Petsas A., Tsirtsis G., Vagi M., Vlatsiotou F., (2007), Marine monitoring along the eastern coastal area of the island of Lesvos, Greece during 2004 in the framework of MEDPOL III, Global Nest J., 9, 83-97.

2. Dassenakis M., Andrianos H., Depiazi G., Konstantas A., Karabela M., Sakellari A., Scoullos M., (2003)., The use of various methods for the study of metal pollution in marine sediments, the case of Euvoikos Gulf, Greece, Appl. Geochem., 18, 781-794.

3. Davis E.B. (Ed.), (2006), Trends in Environment Research, Nova Science Publishers, Inc., New York, USA.

4. Dockery D.W., Pope C.A., (1994), Acute respiration effects of particulate air pollution, Annu. Rev. Pub. Health, 15, 107-132.

5. EC, (1998), Directive of the European Parliament and of the council 98/83/EC of 11 November 1998 on the Quality of water for human consumption, Off. J. Eur. Commun., L330, 52-54.

6. EU-WHO (2002), Guidelines for concentration and exposure-response measurement of fine and ultra fine particulate matter for use in epidemiological studies, EUR $20238 \mathrm{EN}$.

7. Farmaki E. (2007), Chemometric techniques used for the determination of the pollution sources of aquatic resources from metals, MSc Thesis, Department of Chemistry, National \& Kapodistrian University of Athens.

8. Gikas G.D., Tsihrintzis V.A., Akratos C.S., Haralambidis G., (2008), Water quality trends in 
Polyphytos reservoir, Aliakmon River, Greece, Environ. Monit. Assess., Article in Press, doi: 10.1007/s10661-008-0191-z.

9. Golia E.E., Dimirkou A., Mitsios I.K., (2007), Accumulation of heavy metals on Burley, Virginia and Oriental tobacco leaves grown in an agricultural area in relation to soil, Bull. Environ. Contam. Toxicol., 79, 158-162.

10. Golia E.E., Dimirkou A., Mitsios I.K., (2008a), Levels of heavy metals pollution in different types of soil of central Greece, Bull Environ. Contam. Toxicol., 80, 206-210.

11. Golia E.E., Dimirkou A., Mitsios I.K., (2008b), Influence of some soil parameters on heavy metals accumulation by vegetables grown in agricultural soils of different soil orders, Bull. Environ. Contam. Toxicol., 81, 80-84.

12. Karageorgis A.P., Nikolaidis N.P., Karamanos H., Skoulikidis N., (2003), Water and sediment assessment of the Axios River and its coastal environment, Cont. Self Res., 23, 1929-1944.

13. Karanasiou A.A., Sitaras I.E., Siskos P.A., Size distribution and sources of trace metals and nalkanes in the Athens urban aerosol during summer, Atmos. Environ., 41, 2368-2381.

14. Karavoltsos S., Sakellari A., Mihopoulos N., Dassenakis M., Scoullos M., (2008), Evaluation of the quality of drinking water in regions of Greece, Desalination, 224, 317-329.

15. Ladakis M., Belias C., Triantafyllaki S., Dassenakis M., Scoullos M., (2007), The distribution of $\mathrm{Cd}$ and $\mathrm{Cu}$ in sediments covered with algal mat, Global Nest J., 9, 243-250.

16. Manalis N., Grivas G., Protonotarios V., (2005), Toxic metal content of particulate matter (PM10), within the Greater Area of Athens, Chemosphere, 60, 557-566.

17. Martin J.A.R., Arias M.L., Corbí J.M.G., (2006), Heavy metals contents in agricultural topsoils in the Ebro basin (Spain). Application of the multivariate geostatistical methods to study spatial variations, Environ. Pollut. 112, 152-161

18. Mattas C., Soulios G., Panagopoulos A., Voudouris K., Panoras A., (2007), Hydrochemical characteristics of the Gallikos river water, prefecture of Kilikis, Greece, Global Nest J., 9, 251258.

19. Merian E. (Ed.), (1991), Metals and Their Compounds in the Environment - Occurrence, Analysis and Biological Relevance, $\mathrm{VCH}$, Weinheim, Germany.

20. Michopoulos P., Baloutsos G., Economou A., Nikolis N., Bakeas E.B., Thomaidis N.S., (2005), Biochemistry of lead in an urban forest in Athens, Greece, Biogeochemistry, 73, 345-357.

21. Michopoulos P., Baloutsos G., Economou A., Samara C., Thomaidis N.S., Grigoratos T., (2007), Nutrient cycling and foliar status in an urban pine forest in Athens, Greece, Plant Soil, 294, 31-39.

22. Micó C., Peris M., Recatalà L., Sànchez J., (2007), Baseline values for heavy metals in agricultural soils in an European Mediterranean region, Sci. Total Environ., 378,13-17.

23. Mitsios I.K., Golia E.E., Tsadilas C.D., (2005) Heavy metal concentration in soils and irrigation water in Thessaly area, Central Greece, Commun. Soil Sci. Plant Anal., 36, 487-501.

24. Ochsenkuhn K.M., Ochsenkuhn-Petropoulou M., Heavy metals in airborne particulate matter of an industrial area in Attica, Greece and their possible sources, Fresen. Environ., Bull., 17, 455-462.

25. Pantera A., Papadopolulos A. M., Orfanoudakis M., (2007), Trace element accumulation in tree rings of Pinus Halepensis during the last 140 years, Global Nest J., 9, 286-292.

26. Papafilippaki A., Gasparatos D., Haidouti C., Stavroulakis G., (2007), Total and bioavailable forms of $\mathrm{Cu}, \mathrm{Zn}, \mathrm{Pb}$ and $\mathrm{Cr}$ in agricultural soils: A study from the hydrological basin of Keritis, Chania, Greece, Global Nest J., 9, 201-206.

27. Peris M., Micó C., Recatalà L., Sànchez R., Sànchez J., (2007), Heavy metal contents in horticultural crops of a representative area of the European Mediterranean region, Sci. Total Environ., 378, 42-48.

28. Pisinaras V., Petalas C., Gemitzi A., Tsihrinzis V.A., (2007), Water quantity and quality monitoring of Kosynthos river, north-eastern Greece, Global Nest J., 9, 259-268.

29. Riga-Karandinos A.N., Saitanis C.J., Arapis G., (2006), First study of anthropogenic platinum group elements in roadside top-soils in Athens, Greece, Water Air Soil Poll., 172, 3-20.

30. Rowell D.L., (1994), Soil science, methods and applications, Longman, UK.

31. Samara C., Voutsa D., (2005), Size distributions of airborne particulate matter and associated heavy metals in the roadside environment, Chemosphere, 59, 1197-1206.

32. Scoullos M.J., Sakellari A., Giannopolulou K., Paraskevopoulou V., Dassenakis M., (2007), Dissolved and particulate trace metal levels in the Saronikos Gulf, Greece, in 2004. The 
impact of the primary Wastewater Treatment Plant of Psittalia, Desalination, 210, 98-109.

33. Simeonov V., Stratis J.A., Samara C., Zachariadis G., Voutsa D., Anthemidis A., Sofoniou M., Kouimtzis Th., (2003), Assessment of the surface water quality in Northern Greece, Water Res., 37, 4119-4124.

34. Stamatis G., Lambrakis N., Alexakis D., Zagana E., (2006), Groundwater quality in Mesogia basin in eastern Attica (Greece), Hydrol. Process., 20, 2803-2818.

35. Thomaidis N.S., Bakeas E.B., Siskos P.A., (2003), Characterization of lead, cadmium, arsenic and nickel in PM2:5 particles in the Athens atmosphere, Greece, Chemosphere, 52, 959-966.

36. Vassilakos C., Veros D., Michopoulos J., (2007)., Estimation of selected heavy metals and arsenic in PM10 aerosols in the ambient air of the Greater Athens Area, Greece, J. Hazard. Mater., 140, 389-398.

37. W.H.O. (1984), Guidelines for drinking-water quality. Vol. 2, Health criteria and other supporting information, Geneva.

38. Whittaker R.H., Likens G.E., Bormann F.H., Eaton J.S., Siccama T.G., (1979), The Hubbard Brook ecosystem study: forest nutrient cycling and element behaviour, Ecology, 60, 203-220.

39. Wong S.C., Li X.D., Zhang G., Qi S.H., Min Y.S., (2002), Heavy metals in agricultural soils of the Pearl River Delta, south China, Environ. Pollut. 119, 33-44.

40. Yoon J., Cao X., Zhou Q., Ma L.Q., (2007), Accumulation of Pb, Cu and $\mathrm{Zn}$ in native plants growing on a contaminated Florida site, Sci. Total Environ., 368, 456-464. 